\title{
1 Adsorption Isotherm and Kinetic Studies of Hexavalent Chromium Removal from Aqueous Solution onto Bone Char
}

${ }^{1}$ Department of Land and Water Resources Engineering Royal Institute of Technology, SE-100 44, Stockholm, Sweden 
31 The adsorption of hexavalent chromium [Cr(VI)] onto bone char was optimised as a function of

$32 \mathrm{pH}$, initial $\mathrm{Cr}(\mathrm{VI})$ concentration, and bone char dosage using aqueous solution in batch tests. The

33 initial $\mathrm{Cr}(\mathrm{VI})$ concentrations were varied between 5 and $800 \mathrm{mg} / \mathrm{L}$ to investigate equilibrium,

34 kinetics, and the adsorption isotherms . About $100 \%$ of $\mathrm{Cr}(\mathrm{VI})$ was removed at initial pH of 1.0

35 with initial $\mathrm{Cr}(\mathrm{VI})$ concentration of $10 \mathrm{mg} / \mathrm{L}$, using $2 \mathrm{~g}$ of bone char after 2 hours. The maximum

36 adsorption capacity of the bone char was $4.8 \mathrm{mg} / \mathrm{g}$ for an initial $\mathrm{Cr}(\mathrm{VI})$ concentration of 800

$37 \mathrm{mg} / \mathrm{L}$. The adsorption kinetics of $\mathrm{Cr}(\mathrm{VI})$ onto bone char followed a second order kinetic model.

38 The adsorption isotherm followed the Langmuir model for $\mathrm{Cr}$ (VI) adsorption . In general, bone

39 char demonstrated promising results as an effective adsorbent for removal of $\mathrm{Cr}(\mathrm{VI})$ from the

40 aqueous solution. The results from this study could be useful in designing a filtration unit with

41 bone char as the adsorbent in a full-scale water and wastewater treatment plant for the removal of

$42 \mathrm{Cr}(\mathrm{VI})$ from contaminated water.

44 Keywords: Adsorption, Bone char, Reaction kinetics, Equilibrium concentration, Isotherms 


\section{1. Introduction}

58 Chromium is considered as the $21^{\text {st }}$ most abundant element in the world with a concentration of

59 about $122 \mathrm{mg} / \mathrm{L}$ in the aqueous solution [1]. As a key contaminant in surface water and

60 groundwater, Chromium is generated from various industrial activities including electroplating,

61 tannery, automobile, pigments, paper and pulp, fertilizer, textile, steel, and metal finishing

62 industries $[1,2]$. Trivalent $(\mathrm{Cr}(\mathrm{III}))$ and hexavalent chromium $(\mathrm{Cr}(\mathrm{VI}))$ are the two major

63 oxidation states of chromium that are detected in industrial effluents. Depending on the variation

64 of redox potential (Eh)-pH, the change of chromium species is shown in Fig. 1. According to

65 Fig. 1, $\mathrm{Cr}(\mathrm{III})$ is the most stable state thermodynamically under the reducing condition. $\mathrm{Cr}(\mathrm{VI})$

66 remains stable under likely oxidizing condition. $\mathrm{Cr}(\mathrm{III})$ predominates at $\mathrm{pH}$ below 3.0. The

67 hydrolysis of aqueous $\mathrm{Cr}(\mathrm{III})$ tends to convert trivalent chromium into hydroxy species at $\mathrm{pH}$

68 above 3.5. The hydroxy species includes $\mathrm{CrOH}^{2+}, \mathrm{Cr}(\mathrm{OH})_{2}{ }^{+}, \mathrm{Cr}(\mathrm{OH})_{3}{ }^{0}$ and $\mathrm{Cr}(\mathrm{OH})_{4}{ }^{-}[3] . \mathrm{Cr}(\mathrm{VI})$

69 is more toxic compared to the $\mathrm{Cr}$ (III) species and has severe adverse impacts from simple skin

70 irritation to lung carcinoma [4, 5, 6]. The US Environmental Protection Agency (EPA)

71 recommended that the maximum allowable limit for $\mathrm{Cr}(\mathrm{VI})$ should be $0.1 \mathrm{mg} / \mathrm{L}$ for discharge

72 into inland surface waters, and $0.05 \mathrm{mg} / \mathrm{L}$ in potable water [7].

74 Metal ions cannot degrade into harmless end products like organic pollutants, which are bio-

75 degradable [8]. In view of its toxic nature, suitable treatment methods for $\mathrm{Cr}(\mathrm{VI})$ removal from

76 industrial wastewater and groundwater resources are being developed and applied. The common

77 treatment methods include precipitation $[9,10]$, ion exchange $[11,12]$, membrane separation (i.e.

78 ultrafiltration and reverse osmosis) [13, 14], reduction and electrochemical reduction [15].

79 However, most of the above mentioned treatment technologies have limitations which include 
80 the generation of toxic sludge, high operation and maintenance expenditure, high energy

81 requirements, long treatment times, and poor removal efficiencies [1, 15].

83 Adsorption processes have been shown to be effective and low-cost techniques for the removal

84 of a variety of metal ions, including chromium from aqueous solutions. The significant benefits

85 of adsorption processes include effective and economical contaminant removal, recovery and

86 recycling of adsorbed metals from adsorbent, low sludge production, simple process and high

87 removal efficiencies $[1,16,17]$. As an effective and economical adsorbent, activated carbon has

88 been widely employed for wastewater treatment [17]. In addition, other low cost adsorbents have

89 also been reported for $\mathrm{Cr}(\mathrm{VI})$ removal from wastewater, including maple saw dust [18],

90 bentonite and expanded perlite [19], Nymphaea rubra [20], Pseudomonas aeruginosa and

91 Bacillus subtilis [21], and Mucor racemosus [22].

92

93 However, bone char has only been rarely investigated as an adsorbent for metal removal from

94 aqueous systems [10, 23]. Thus, a significant knowledge gap exists for the possible use of this

95 low-cost biomass derived material as a possible economically viable adsorbent to remove metal

96 from aqueous systems. Bone char is a heterogenous adsorbent [24], which is produced from the

97 destructive distillation of dried, crushed cattle bones. Typically, it has been utilized in the sugar

98 industry for the removal of color by sorption. The bones from cattle, goat, sheep, chicken etc. are

99 accumulating day by day as waste materials and require proper solid waste management. The

100 utilization of this bone for the synthesis of bone char, which can be used as an adsorbent to

101 remove contaminants from the wastewater, can provide a better solution for the waste

102 management [25]. Therefore, the main objective of the present study was to evaluate the 
103 performance of bone char, a waste product, generated from calcination of cattle bone for the

104 removal of $\mathrm{Cr}(\mathrm{VI})$ from aqueous systems. The secondary objectives were to optimize the

105 operational parameters, including $\mathrm{pH}$, adsorbent dose, initial $\mathrm{Cr}(\mathrm{VI})$ concentration and contact

106 time for the maximum $\mathrm{Cr}(\mathrm{VI})$ removal from the wastewater, and to also perform equilibrium and

107 kinetics studies for $\mathrm{Cr}(\mathrm{VI})$ removal.

108

109 2. Experimental

$110 \quad 2.1$ Preparation and characterization of bone char

111 The bone char used in this study was purchased from Anthracite Filter Media (AFM), Culver

112 City, California, USA and the composition was provided by the company as shown in Table 1 . It

113 is a carbonaceous granular solid material prepared by calcining cattle bones at $450^{\circ} \mathrm{C}$. The bone-

114 char was crushed and sieved to get the particle sizes between 53 and $250 \mu \mathrm{m}$ to increase its

115 surface area because increased surface area might promote high adsorption of $\mathrm{Cr}(\mathrm{VI})$ onto the

116 bone char [26]. The surface area and pore volume of the reduced particle size of bone char were

117 determined using a NOVA 1200 surface area analyzer (Quantachrome Instruments, version 2.0,

118 Boynton Beach, FL) with the Bruanuer-Emmett-Teller (BET) nitrogen adsorption method at

$11977^{\circ} \mathrm{K}$ of temperature.

120

$121 \quad 2.2$ Adsorption procedure

122 The optimum $\mathrm{pH}$, bone char dosage, and initial $\mathrm{Cr}(\mathrm{VI})$ concentration were determined by batch

123 adsorption studies. The optimum parameters were then used to analyze adsorption capacity,

124 adsorption reaction kinetics, and equilibrium isotherm.

125 
126 About $2.8269 \mathrm{~g}$ of potassium dichromate $\left(\mathrm{K}_{2} \mathrm{Cr}_{2} \mathrm{O}_{7}\right)$ salt (Sigma-Aldrich LTD, USA) was

127 dissolved in deionized water to prepare the stock solution of $1000 \mathrm{mg} / \mathrm{L}$ of $\mathrm{Cr}(\mathrm{VI})$. The stock

128 solution of $\mathrm{Cr}(\mathrm{VI})$ was subsequently diluted using deionized water to the required working

129 concentration prior to use in the batch tests. The $\mathrm{pH}$ of the solution was varied by using either

130 about $15.8 \mathrm{M} \mathrm{HNO}_{3}$ or $1 \mathrm{M} \mathrm{NaOH}$. The $\mathrm{Cr}(\mathrm{VI})$ and bone char mixture was placed on a platform

131 shaker (New Brunswick Scientific, model: Innova 2300) at $150 \mathrm{rpm}$ at room temperature during

132 the tests. Typically, about $2 \mathrm{~g}$ of bone char was added to a $50 \mathrm{~mL}$ solution of $10 \mathrm{mg} / \mathrm{L}$

133 concentration of $\mathrm{Cr}(\mathrm{VI})$.

135 About $1 \mathrm{~mL}$ sample was collected using separate syringes at $0.5,1,2$ to $24 \mathrm{~h}$ and $1 \mathrm{~mL}$ sample 136 was collected in each day from day 2 - 6 from the same testing solution. The collected samples 137 were then filtered through $0.45 \mu \mathrm{m}$ syringe filter (Sterlitech, Kent, WA, USA). Filtered samples 138 were stored in glass bottles and preserved, when necessary, in the refrigerator at $4{ }^{\circ} \mathrm{C}$ with sample $139 \mathrm{pH}$ below 2 to avoid the degradation of $\mathrm{Cr}(\mathrm{VI})$ concentration. The samples were then analyzed to 140 measure the $\mathrm{Cr}(\mathrm{VI})$ concentrations using a graphite furnace equipped atomic absorption

141 spectrophotometer (GF-AAS) with an air-acetylene flame and chromium hollow cathode lamp at 142 a slit of $2 \mathrm{~nm}$ and wavelength of $357.9 \mathrm{~nm}$. Prior to sample analysis, the GF-AAS instrument was 143 calibrated regularly.

145 All batch tests were performed in duplicate, and average values were used in the plots presented 146 here. The experimental blanks were run in parallel. All working solutions were prepared freshly 147 prior to use in the batch tests. The glassware were presoaked in $5 \% \mathrm{HNO}_{3}$ solution overnight and 148 then washed with tap water, rinsed three times with deionized water and dried in air before use. 


\subsection{Effects of operating parameters and equilibrium studies}

150 The optimum $\mathrm{pH}$ was determined by using solution $\mathrm{pHs}$ of 1,2 to 9 with bone char dosage of 2

$151 \mathrm{~g} / 50 \mathrm{~mL}$ solution. Subsequently, different bone char dosages of 0.5, 1, 2 and $3 \mathrm{~g}$ in $50 \mathrm{~mL} \mathrm{Cr}$ (VI)

152 solutions were used to identify the optimum bone char dosage at the predetermined optimum

$153 \mathrm{pH}$. The initial $\mathrm{Cr}(\mathrm{VI})$ concentration was kept at $10 \mathrm{mg} / \mathrm{L}$ to investigate optimum $\mathrm{pH}$ and bone

154 char dosage. The initial Cr(VI) concentrations of 5, 10, 20, 50 to $800 \mathrm{mg} / \mathrm{L}$ [27] were evaluated

155 with $2 \mathrm{~g}$ of optimum bone char dosage in $50 \mathrm{~mL}$ solution at optimum $\mathrm{pH}$ to determine the

156 Langmuir and Freundlich isotherms properly.

158 The $\mathrm{Cr}(\mathrm{VI})$ concentrations at equilibrium $\left(C_{e}\right)$ and at any particular time $\left(C_{t}\right)$ were evaluated for 159 different initial $\mathrm{Cr}(\mathrm{VI})$ concentrations $\left(C_{0}\right)$ of 5, 10, 20, 50 to $800 \mathrm{mg} / \mathrm{L}$ by maintaining the $\mathrm{pH}$ 160 and bone char dosage constant at the optimum value. These concentrations $\left(C_{0}, C_{e}, C_{t}\right)$ were 161 employed to calculate the adsorption capacity of bone char at any particular time $\left(q_{t}\right)$ and at 162 equilibrium $\left(q_{e}\right)$ according to the mass balance Equations (1) and (2) shown below, respectively

163 [1]. Afterward, these adsorption capacities $\left(\mathrm{q}_{\mathrm{e}}, \mathrm{q}_{\mathrm{t}}\right)$ were used to determine the equilibrium

164 adsorption isotherms and the kinetics model plots.

$165 \quad q_{t}=\left(\frac{C_{0}-C_{t}}{m}\right) V \quad$ Eq. (1)

$166 \quad q_{e}=\left(\frac{C_{0}-C_{e}}{m}\right) V \quad$ Eq. (2)

167 where $C_{0}$ is the initial $\mathrm{Cr}(\mathrm{VI})$ concentration in $\mathrm{mg} / \mathrm{L}, C_{t}$ is the $\mathrm{Cr}(\mathrm{VI})$ concentration at a particular

168 time in solution in $\mathrm{mg} / \mathrm{L}, C_{e}$ is the equilibrium $\mathrm{Cr}(\mathrm{VI})$ concentration in $\mathrm{mg} / \mathrm{L}, V$ is the volume of 169 the solution in litter (L), and $m$ is the dry mass of bone char in gram $(\mathrm{g})$. 
172 The Langmuir and Freundlich models are expressed linearly in Equations (3) and (4),

173 respectively to evaluate the adsorption isotherms of $\mathrm{Cr}(\mathrm{VI})$ onto bone char [28, 29].

$174 \frac{1}{q_{e}}=\frac{1}{q_{m} K_{L}} \cdot \frac{1}{C_{e}}+\frac{1}{q_{m}} \quad$ Eq. (3)

$175 \quad \log \left(q_{e}\right)=\frac{1}{n} \log \left(C_{e}\right)+\log \left(K_{F}\right) \quad$ Eq. (4)

176 where $C_{e}$ denotes the equilibrium $\mathrm{Cr}(\mathrm{VI})$ concentration in $\mathrm{mg} / \mathrm{L}, q_{e}$ represents the equilibrium

177 adsorption capacity of bone char in $\mathrm{mg} / \mathrm{g}, q_{m}$ is the maximum adsorbed amount of $\mathrm{Cr}(\mathrm{VI})$ per

178 mass of bone char in $\mathrm{mg} / \mathrm{g}, K_{L}$ is the Langmuir equilibrium adsorption constant (L/mg) related to

179 the free energy of adsorption [30], $K_{F}$ is the Freundlich constant $\left[(\mathrm{mg} / \mathrm{g})(\mathrm{L} / \mathrm{mg})^{1 / \mathrm{n}}\right]$ related to the

180 strength of the adsorptive bond [30], and $1 / n$ is the adsorption intensity factor or surface

181 heterogeneity (unit less).

182

183 The Langmuir isotherm indicates that the free energy of adsorption is independent on the surface

184 coverage of adsorption sites and the solid surface saturation occurs by a monolayer coverage of

185 adsorbate at high $C_{e}$ values and a linear relationship at low $C_{e}$ values [8]. To effectively evaluate

186 the Langmuir isotherm, the values of $1 / q_{e}$ were plotted against $1 / C_{e}$ and the values of $K_{L}$ and $q_{m}$

187 were calculated using the slope and intercept of the best fit line, respectively. Furthermore, the

188 values of $\log q_{e}$ and $\log C_{e}$ were plotted to evaluate the Freundlich isotherm parameters of $1 / n$ and

$189 K_{F}$. The Freundlich constant, $K_{F}$ represents the quantity of adsorbed metal ions for a unit

190 equilibrium concentration (i.e. $C_{e}=1$ ) [31]. The regression coefficients $\left(R^{2}\right)$ values were used to

191 evaluate the fit of the Langmuir and Freundlich isotherms to the experimental data. The isotherm

192 that had $R^{2}$ value nearest to 1.0 was selected as the operating adsorption isotherm and used for 
193 the adsorption of $\mathrm{Cr}(\mathrm{VI})$ onto bone char. For Langmuir sorption, $\mathrm{R}_{\mathrm{L}}$, a dimensionless separation

194 factor was used to describe the type of isotherm and was expressed in Equation (5) [32].

$195 \quad \mathrm{R}_{\mathrm{L}}=1 /\left(1+\mathrm{K}_{\mathrm{L}} \mathrm{C}_{0}\right)$

196 where $\mathrm{C}_{0}(\mathrm{mg} / \mathrm{L})$ and $\mathrm{K}_{\mathrm{L}}(\mathrm{L} / \mathrm{mg})$ are initial metal concentration and Langmuir constant,

197 respectively. Thus, the value of $\mathrm{R}_{\mathrm{L}}$ identifies whether the adsorption process is favourable or

198 unfavourable. The process is irreversible for $\mathrm{R}_{\mathrm{L}}=0$, favourable for $\mathrm{R}_{\mathrm{L}}<1$, linear for $\mathrm{R}_{\mathrm{L}}=1$ and

199 unfavourable for $\mathrm{R}_{\mathrm{L}}>1$ [8].

200

$201 \quad 2.5$ Determination of sorption reaction kinetics (First and Second order)

202 The pseudo first-order (Equation 6) and second-order kinetics (Equation 7) shown below were

203 used to describe the adsorption reaction kinetics of $\mathrm{Cr}(\mathrm{VI})$ onto bone char [33, 34].

$204 \log \left(q_{e}-q_{t}\right)=-\frac{K_{1}}{2.303} t+\log q_{e} \quad$ Eq. (6)

$205 \frac{t}{q_{t}}=\frac{1}{q_{e}} t+\frac{1}{K_{2} \cdot q_{e}^{2}} \quad$ Eq. (7)

206 where $q_{e}$ and $q_{t}$ represent the adsorption capacities $(\mathrm{mg} / \mathrm{g})$ of bone char at equilibrium and at a

207 particular time $t(\mathrm{~h})$, respectively. The first-order and second-order kinetic rate constants are

208 denoted by $K_{l}\left(\mathrm{~h}^{-1}\right)$ and $K_{2}\left(\mathrm{~g} \cdot \mathrm{mg}^{-1} \cdot \mathrm{h}^{-1}\right)$.

209

210 The pseudo first order kinetic model was established by plotting the value of $\log \left(q_{e}-q_{t}\right)$ vs time

$211(t)$ to determine the values of $K_{l}, q_{e}$, and $R^{2}$. However, the values of $t / q_{t}$ were plotted against time

$212(t)$ in order to establish the pseudo second order kinetic model and to calculate the values of $K_{2}$,

$213 q_{e}$, and $R^{2}$. The regression coefficients $\left(R^{2}\right)$ of the first and second order kinetic model were

214 compared to check which of the models is suitable for $\mathrm{Cr}(\mathrm{VI})$ adsorption onto bone char. The 
215 deviation of equilibrium adsorption capacity $\left(q_{e}\right)$ obtained from the models, and the

216 experimentally obtained value was also calculated.

\section{$218 \quad 2.6$ Statistical Analysis}

219 Independent two-sample t- test was performed at a 95\% confidence interval between the

220 replicate values obtained during the tests to determine whether or not the replicate values were 221 significantly different. To verify the optimum $\mathrm{pH}$ values, bone char dosage, and initial $\mathrm{Cr}(\mathrm{VI})$

222 concentration for maximum percentage removal of $\mathrm{Cr}(\mathrm{VI})$, a one-way ANOVA test was

223 conducted at a 95\% confidence interval. In addition, the one-way ANOVA test was also

224 performed to identify the effects of initial $\mathrm{Cr}(\mathrm{VI})$ concentration on the adsorption capacity of 225 bone char. A Tukey Honestly Significant Difference (HSD) test was performed for multiple 226 comparisons when the ANOVA test showed significant differences $(p$ value $<0.05)$.

\section{3. Results and discussions}

\subsection{Textural properties of bone char}

230 After reducing the particle size between 53 and $250 \mu \mathrm{m}$, the surface area (BET), pore volume, 231 and average pore diameter were found to be $105 \mathrm{~m}^{2} / \mathrm{g}, 0.05253 \mathrm{~cm}^{3} / \mathrm{g}$ and $1.999 \mathrm{~nm}$,

232 respectively. The surface area of the particles did not increase significantly. The pore volume 233 was observed to decrease from $0.225 \mathrm{~cm}^{3} / \mathrm{g}$ to $0.05253 \mathrm{~cm}^{3} / \mathrm{g}$, which is over $75 \%$ due to size 234 reduction as expected.

\subsection{Effect of solution pH}


237 The $\mathrm{Cr}(\mathrm{VI})$ removal efficiencies were observed to decrease consistently with increase in $\mathrm{pH}$ from 238 1- 9. The removal efficiencies were observed to increase slightly with time at all $\mathrm{pH}$ values as 239 shown in Fig. 2A. At a pH of 1, the $\mathrm{Cr}(\mathrm{VI})$ removal efficiency was about $85 \%$ after $0.5 \mathrm{~h}$ of 240 adsorption reaction, and increased to $98 \%$ after $2 \mathrm{~h}$. The removal efficiencies were about $60 \%$, $24145 \%, 43 \%, 35 \%$, and $32 \%$ at $\mathrm{pHs}$ of $2,3,5,7$, and 9 , respectively, after $2 \mathrm{~h}$ of reaction. Since

242 the highest removal efficiency was obtained at the lowest $\mathrm{pH}$ of 1 by using bone char sample, the 243 optimum $\mathrm{pH}$ was considered to be 1. Dahbi et al [35] have also recommended the same optimum $244 \mathrm{pH}$. At low $\mathrm{pH}$ values, the dominant species of $\mathrm{Cr}(\mathrm{VI})$ in solution is $\mathrm{HCrO}_{4}{ }^{-}$. This is converted to $245 \mathrm{CrO}_{4}{ }^{2-}$ and $\mathrm{Cr}_{2} \mathrm{O}_{7}{ }^{2-}$ ions as the $\mathrm{pH}$ increases. The adsorption free energy change for $\mathrm{HCrO}_{4}{ }^{-}$is 246 lower than those of $\mathrm{CrO}_{4}{ }^{2-}$ and $\mathrm{Cr}_{2} \mathrm{O}_{7}{ }^{2-}$ ions. Therefore, $\mathrm{HCrO}_{4}{ }^{-}$is more easily adsorbed than $247 \mathrm{CrO}_{4}{ }^{2-}$ and $\mathrm{Cr}_{2} \mathrm{O}_{7}{ }^{2-}$ at lower $\mathrm{pH}$ values [36]. Moreover, bone char has been reported to exhibit 248 positively charged surface species due to surface group protonation at low $\mathrm{pH}$ values, thus 249 leading to the binding of anionic species of $\mathrm{Cr}(\mathrm{VI})$ by an electrostatic attraction between the 250 bone chars and $\mathrm{Cr}(\mathrm{VI})$ anions $[37,38]$ and also resulted in a final $\mathrm{pH}$ increase. Since $\mathrm{Ca}^{2+}$ might 251 dissociate from the bone surface at lower $\mathrm{pH}$, metal ions could be exchanged easily in the site of $252 \mathrm{Ca}^{2+}[39]$. The exchangeable metal ion could be $\mathrm{Cr}(\mathrm{III})$ because $\mathrm{Cr}(\mathrm{VI})$ could be reduced to $253 \mathrm{Cr}(\mathrm{III})$ at $\mathrm{pH}$ below 3.0 (Fig.1). At higher $\mathrm{pH}$ values, $\mathrm{OH}^{-}$and $\mathrm{Cr}(\mathrm{VI})$ species $\left(\mathrm{CrO}_{4}{ }^{2-}\right.$ and $\mathrm{Cr}_{2} \mathrm{O}_{7}{ }^{2-}$ 254 ) compete for the same adsorption site on the bone char, resulting in a lower removal of $\mathrm{Cr}(\mathrm{VI})$ $255[23,40]$. In addition, surface $\mathrm{OH}^{-}$ions of bone char increase with an increase in $\mathrm{pH}$, resulting in a 256 more Coulombic repulsion of $\mathrm{CrO}_{4}{ }^{2-}$ and $\mathrm{Cr}_{2} \mathrm{O}_{7}{ }^{2-}$ species [10, 41]. Thus, $\mathrm{Cr}(\mathrm{VI})$ removal 257 efficiency is higher at lower $\mathrm{pHs}$ as compared to that of higher $\mathrm{pHs}$. 
The one-way ANOVA test results show that the percentage $\mathrm{Cr}(\mathrm{VI})$ removal was significantly

260 different for various $\mathrm{pH}$ values used in the experiment. Therefore, Tukey HSD test, as shown in

261 Table 2, was performed for multiple comparisons among various pHs. The percentage $\mathrm{Cr}(\mathrm{VI})$

262 removal was significantly different between $\mathrm{pH}$ values except between 3 and 5 , and 7 and 9 .

263 Since the percentage removal of $\mathrm{Cr}(\mathrm{VI})$ is maximum at $\mathrm{pH} 1$ as shown in Fig. 2A, and also

264 Tukey HSD test indicates that the $\mathrm{Cr}(\mathrm{VI})$ removal at $\mathrm{pH} 1$ is significantly different than that of

265 other $\mathrm{pH}$ values, then $\mathrm{pH} 1$ can be considered as the optimum $\mathrm{pH}$.

\section{$267 \quad 3.3$ Effect of bone char dosages}

268 As expected, the increase in bone char dosage from $0.5-3 \mathrm{~g}$ resulted in sharp increases in

269 removal efficiencies of $\mathrm{Cr}(\mathrm{VI})$ as shown in Fig. 2B. The highest percentage of $\mathrm{Cr}(\mathrm{VI})$ removal

270 was observed for the highest studied bone char dosage of $3 \mathrm{~g}$. About $95 \% \mathrm{Cr}$ (VI) removal was

271 occurred within the first $0.5 \mathrm{~h}$, and this increased to $100 \%$ in about $1.5 \mathrm{~h}$ for bone char dosage of

$2723 \mathrm{~g}$. For bone char dosage of $2 \mathrm{~g}$, about $100 \% \mathrm{Cr}(\mathrm{VI})$ removal was also observed after $2 \mathrm{~h}$. For the

273 same $2 \mathrm{~h}$ of experimental adsorption reaction, the removal efficiencies were about $60 \%$ and $66 \%$

274 for bone char dosages of $0.5 \mathrm{~g}$ and $1 \mathrm{~g}$, respectively. Since the removal efficiencies were similar

275 (100\%) for bone char dosages of $2 \mathrm{~g}$ and $3 \mathrm{~g}$ after $2 \mathrm{~h}$, bone-char dosage of $2 \mathrm{~g}$ was considered

276 to be the optimum value for purposes of our studies. Another previous study has also

277 recommended similar optimum value of bone char dosage for $\mathrm{Cr}(\mathrm{VI})$ adsorption [35].

279 The one-way ANOVA test results show that the percentage $\mathrm{Cr}(\mathrm{VI})$ removal was significantly

280 different for various bone char dosages used in the experiment. By using Tukey HSD test, it was

281 observed that the percentage $\mathrm{Cr}(\mathrm{VI})$ removal is significantly different by using bone char 
282 dosages of $0.5 \mathrm{~g}$ and $2 \mathrm{~g}(\mathrm{HSD}=41.25>11.1), 0.5 \mathrm{~g}$ and $3 \mathrm{~g}(\mathrm{HSD}=45.5>11.1), 1 \mathrm{~g}$ and $2 \mathrm{~g}(\mathrm{HSD}$

$283=31>11.1), 1 \mathrm{~g}$ and $3 \mathrm{~g}(\mathrm{HSD}=35.25>11.1)$. There is no significant $\mathrm{Cr}(\mathrm{VI})$ removal difference

284 between $2 \mathrm{~g}$ and $3 \mathrm{~g}$ of bone char dosage. Therefore, bone char dosage of $2 \mathrm{~g}$ can be considered as 285 an optimum dosage.

\section{$287 \quad 3.4$ Effects of initial Cr(VI) concentration}

288 At optimum $\mathrm{pH}$ and bone char dosage, $\mathrm{Cr}(\mathrm{VI})$ removal efficiency generally decreased with 289 increase in initial Cr(VI) concentration as shown in Fig. 2C. The removal efficiencies also 290 increased with time at all initial Cr(VI) concentrations. For an initial Cr(VI) concentration of 5

$291 \mathrm{mg} / \mathrm{L}$, the $\mathrm{Cr}(\mathrm{VI})$ removal efficiency was around $94 \%$ after $0.5 \mathrm{~h}$, and this increased to the 292 highest value of about $100 \%$ after 2 h. Similar trends were observed for all the other initial 293 Cr(VI) concentrations studied. The removal efficiencies reached maximum values of about $98 \%$, $29495 \%, 88 \%, 85 \%, 82 \%, 71 \%$ and $22 \%$ for initial $\mathrm{Cr}(\mathrm{VI})$ concentrations of $10,20,50,70,90,100$ 295 and $800 \mathrm{mg} / \mathrm{L}$, respectively, in $2 \mathrm{~h}$ (all data are not presented in Fig. 2C). Since the removal 296 efficiencies were almost similar for both the initial $\mathrm{Cr}(\mathrm{VI})$ concentration of 5 and $10 \mathrm{mg} / \mathrm{L}$ after $2972 \mathrm{~h}$ of adsorption reaction, $10 \mathrm{mg} / \mathrm{L}$ of $\mathrm{Cr}(\mathrm{VI})$ was considered to be the optimum initial 298 concentration in the present study. Another study has also reported similar optimum value for 299 initial chromium concentration [35].

301 The one-way ANOVA test also shows that the percentage of $\mathrm{Cr}(\mathrm{VI})$ removal was significantly 302 different when initial Cr(VI) concentrations were varied from $5 \mathrm{mg} / \mathrm{L}$ to $800 \mathrm{mg} / \mathrm{L}$. Therefore, 303 Tukey HSD test was performed and found that the percentages of $\mathrm{Cr}(\mathrm{VI})$ removal were 304 significantly different between $5 \mathrm{mg} / \mathrm{L}$ and $50 \mathrm{mg} / \mathrm{L}, 5 \mathrm{mg} / \mathrm{L}$ and $70 \mathrm{mg} / \mathrm{L}, 5 \mathrm{mg} / \mathrm{L}$ and $90 \mathrm{mg} / \mathrm{L}$, 
$5 \mathrm{mg} / \mathrm{L}$ and $100 \mathrm{mg} / \mathrm{L}$ and so on. Eventhough there were not significant differences in

306 percentages of $\mathrm{Cr}(\mathrm{VI})$ removal between $5 \mathrm{mg} / \mathrm{L}$ and $10 \mathrm{mg} / \mathrm{L}, 5 \mathrm{mg} / \mathrm{L}$ and $20 \mathrm{mg} / \mathrm{L}$, the optimum

307 initial $\mathrm{Cr}(\mathrm{VI})$ concentration was considered to be $10 \mathrm{mg} / \mathrm{L}$ because the percentages of $\mathrm{Cr}(\mathrm{VI})$

308 removal were similar (100\%) at initial $\mathrm{Cr}(\mathrm{VI})$ concentration of 5 and $10 \mathrm{mg} / \mathrm{L}$ and $95 \%$ at 20

$309 \mathrm{mg} / \mathrm{L}$ after $2 \mathrm{~h}$ as shown in Fig. 2C.

\subsection{Evaluations of the adsorption capacities}

312 The adsorption capacity $\left(\mathrm{q}_{\mathrm{t}}\right)$ was found to increase with an increase in the initial $\mathrm{Cr}(\mathrm{VI})$

313 concentrations from 5 to $800 \mathrm{mg} / \mathrm{L}$ until it reached equilibrium value $\left(\mathrm{q}_{\mathrm{e}}\right)$ as shown in Fig. 3. The

314 lowest adsorption capacity of $0.13 \mathrm{mg} / \mathrm{g}$ was found after $3 \mathrm{~h}$ for the lowest studied initial $\mathrm{Cr}(\mathrm{VI})$

315 concentration of $5 \mathrm{mg} / \mathrm{L}$. However, the highest adsorption capacity of $4.8 \mathrm{mg} / \mathrm{g}$ was obtained

316 after $5 \mathrm{~h}$ for the highest studied initial $\mathrm{Cr}(\mathrm{VI})$ concentration of $800 \mathrm{mg} / \mathrm{L}$. The adsorption

317 capacities reached constant equilibrium values of $0.25,0.5,1.25,1.75,2.5$ and $3.62 \mathrm{mg} / \mathrm{g}$ for

318 initial $\mathrm{Cr}(\mathrm{VI})$ concentrations of 10, 20, 50, 70, 100 and $500 \mathrm{mg} / \mathrm{L}$, respectively. Equilibrium

319 time was not dependent on the initial $\mathrm{Cr}(\mathrm{VI})$ concentration. In general, a more efficient

320 utilization of the adsorption capacity of the adsorbent is expected at a higher initial $\mathrm{Cr}(\mathrm{VI})$

321 concentration due to the greater driving force from concentration gradient [42]. Normally, a

322 higher initial concentration leads to higher collisions between the adsorbent and $\mathrm{Cr}(\mathrm{VI})$ species,

323 resulting in a driving force that is able to overcome all mass transfer resistances between the

324 solid and aqueous phases [43].

325

326 The one-way ANOVA test also shows that the percentage of $\mathrm{Cr}(\mathrm{VI})$ removal was significantly

327 different when initial $\mathrm{Cr}(\mathrm{VI})$ concentrations were varied from $5 \mathrm{mg} / \mathrm{L}$ to $800 \mathrm{mg} / \mathrm{L}$. Therefore, 
329 adsorption capacity onto bone char is maximum at $800 \mathrm{mg} / \mathrm{L}$ of initial $\mathrm{Cr}(\mathrm{VI})$ concentration as

330 shown in Fig. 3.

\subsection{Evaluations of the adsorption isotherms (Langmuir and Freundlich)}

333 The adsorption isotherm of $\mathrm{Cr}(\mathrm{VI})$ onto bone char was evaluated using the plots of Langmuir 334 and Freundlich models as shown in Figs. 4A and 4B. These two models are the most common 335 isotherms used to describe solid-liquid adsorption systems. The isotherm coefficients for these 336 two models are presented in Table 3 . Since, the maximum adsorption capacity $\left(q_{m}\right)$ obtained

337 from the experimental result and Langmuir model was not similar, the deviation of $q_{m}$ value

338 obtained from the experimental result to Langmuir model was $43 \%$. The value of $\mathrm{R}_{\mathrm{L}}(0.27)$, the 339 essential characteristics of Langmuir dimensionless separation factor or equilibrium parameter, 340 indicates the favourable adsorption process of $\mathrm{Cr}(\mathrm{VI})$ to the adsorbate [44].

342 Based on the alignment of the experimental data with the model lines in Figs. 4A and 4B,

343 together with the regression coefficient $\left(R^{2}\right)$, it is clear that the adsorption data of $\mathrm{Cr}(\mathrm{VI})$ onto

344 bone char fit the Langmuir model better with an $R^{2}$ of 0.9871 , as compared to the Freundlich 345 model $\left(R^{2}=0.9745\right)$. The suitability of Langmuir model can be interpreted to mean that the 346 adsorption of $\mathrm{Cr}(\mathrm{VI})$ took place on a homogeneous monolayer surface of bone char, and that $347 \mathrm{Cr}(\mathrm{VI})$ species did not interact with each other during the adsorption process [23]. Table 4 348 represents the values of $q_{m}$ from Langmuir isotherm obtained by using other adsorbents for 349 removing $\mathrm{Cr}(\mathrm{VI})$ reported in other studies $[10,45,46]$. Value of 'n' obtained from Freundlich 
350 isotherm was 1.8, which indicates a good adsorption potential of $\mathrm{Cr}(\mathrm{VI})$ to the bone char [39, $35147]$.

\section{$353 \quad 3.7$ Evaluation of the adsorption kinetic model}

354 To better understand the adsorption behavior of $\mathrm{Cr}(\mathrm{VI})$ onto bone char, the kinetic sorption data

355 were tested based on the pseudo first-order kinetic model as shown in Fig. 5A and the pseudo 356 second-order kinetic model as shown in Fig. 5B for the initial Cr(VI) concentration of $10 \mathrm{mg} / \mathrm{L}$.

357 The plot line of the pseudo first-order kinetic model is not well aligned with the experimental 358 data, showing an $R^{2}$ value of 0.9191 . However, the pseudo second-order kinetic model shows a 359 good linear correlation with an $R^{2}$ value of 1 , and with excellent agreement between the 360 theoretical model line and the experimental data line. The adsorption of $\mathrm{Cr}(\mathrm{VI})$ onto bone char 361 can therefore be described in terms of second order kinetics [48, 49]. Since the experimental data 362 follow the pseudo second-order kinetic model, the uptake of $\mathrm{Cr}(\mathrm{VI})$ onto bone char could take 363 place through chemisorption by generating new chemical species on the bone char surface [23].

364 Moreover, the pseudo second-order kinetic model indicate that the adsorption reaction of Cr(VI) 365 on bone char depend upon the concentration of $\mathrm{Cr}(\mathrm{VI})$ in solution and the amount of bone char 366 needed to adsorb the maximum $\mathrm{Cr}(\mathrm{VI})$ ions from solution at equilibrium. The kinetic parameters 367 and correlation coefficients of the two models tested are summarized in Table 5. The deviation of 368 the experimentally obtained equilibrium adsorption capacities from the value estimated from the 369 pseudo first-order model was $47.3 \%$. However, no deviation was observed for the second-order

370 kinetic model because the experimental value of the equilibrium adsorption capacity $\left(q_{e}\right)$ was

371 similar to the value calculated from the second order kinetic model. 
374 In this study, bone char was used to adsorb $\mathrm{Cr}(\mathrm{VI})$ from the aqueous solution. The optimum

375 value of $\mathrm{pH}$, bone char dosage, and initial $\mathrm{Cr}(\mathrm{VI})$ concentration were found to be $1,2 \mathrm{~g} / \mathrm{L}$, and 10

$376 \mathrm{mg} / \mathrm{L}$, respectively for the highest adsorption level of $\mathrm{Cr}(\mathrm{VI})$ onto bone char. The maximum

377 adsorption capacity of $4.8 \mathrm{mg} / \mathrm{g}$ was obtained after $5 \mathrm{~h}$ of adsorption at initial $\mathrm{Cr}(\mathrm{VI})$

378 concentration of $800 \mathrm{mg} / \mathrm{L}$. The Langmuir model showed a good fit for Cr(VI) adsorption onto

379 the bone char with a regression coefficient $\left(R^{2}\right)$ of 0.9871 . Kinetic analysis of the $\mathrm{Cr}(\mathrm{VI})$

380 adsorption on bone char showed good alignment with a second order reaction model $\left(R^{2}=1\right)$.

381 The results obtained in this study suggest that bone char has the potential to be an economical

382 and efficient adsorbent for $\mathrm{Cr}(\mathrm{VI})$ removal from water and wastewater resources. Therefore, a

383 filtration unit incorporating bone char as adsorbent can be operated based on the optimum

384 conditions, adsorption isotherm and kinetic model obtained in this study in a full-scale water and 385 wastewater treatment plant for the removal of $\mathrm{Cr}(\mathrm{VI})$ from the contaminated waters.

\section{Acknowledgements}

388 This study was made possible by the support of the United States Department of Energy -

389 National Nuclear Security Administration (DOE-NNSA) through the Samuel P. Massie Chair of

390 Excellence program. The contents of this paper are the sole responsibility of the authors and do

391 not reflect the views of the US Department of Energy or the United States government. The

392 authors would like to acknowledge Prof. Jon Petter Gustafsson of the Royal Institute of

393 Technology, Stockholm, Sweden for his valuable supervision of one of the authors (AHMGH)

394 and guidelines.

395

\section{References}


[1] D. Mohan, C. U. Pittman, Activated carbons and low cost adsorbents for remediation of triand hexavalent chromium from water, J. Hazard. Mater. B137 (2006) 762-811.

[2] A. Kabata-Pendias, A.B. Mukherjee, Trace Elements from Soil to Human, Springer-Verlag Berlin Heidelberg, New York, 2007.

[3] USEPA/625/R-00/005, In-situ treatment of soil and groundwater contaminated with

[4] M. Al-Jabari, M. Abualfailat, S. Shaheen, Treating leather tanning wastewater with stone cutting solid waste, Clean-soil, air, water 40 (2012) 206-210.

[5] D. G. Barceloux, D. Barceloux, Chromium, Clin. Toxicol. 37 (1999) 173-194.

[6] C. Pellerin, S.M. Booker, Reflections on hexavalent chromium: health hazards of an industrial heavyweight, Environ. Health Prospect. 108 (2000) 402-407.

[7] EPA, Environmental pollution control alternatives, EPA/625/5-90/025, EPA/625/4-89/023, Cincinnati, US, 1990.

[8] L. Khezami, R. Capart, Removal of chromium (VI) from aqueous solution by activated carbons: kinetic and equilibrium studies, J. Hazard. Mat., B123 (2005) 223-231.

[9] T. A. Kurniawan, G. Y. S. Chan, W. H. Lo, S. Ba-bel, Physico-chemical treatment techniques for wastewater laden with heavy metals, Chem. Eng. J. 118 (2006) 83-98.

[10] D. Mohan, S. Rajput, V. K Singh, P. H. Steele, C. U. Pittman, Modeling and evaluation of chromium remediation from water using low cost bio-char, a green adsorbent, J. Hazard. Mater 188 (2011) 319-333.

[11] S. Rengaraj, K. H. Yeon, and S. H. Moon, Removal of chromium from water and wastewater by ion exchange resins, J. Hazard. Mater. 87 (2001) 273-287.

[12] M.J Rivero, O. Primo, M.I. Ortiz, Modelling of Cr (VI) removal from polluted groundwaters by ion exchange J. Chem. Technol. Biotechnol 79 (2004) 822-829.

[13] M. A. Barakata, E. Schmidt, Polymer-enhanced ultrafiltration process for heavy metals removal from industrial wastewater, Desalination 256 (2010) 90-93.

[14] C. A. Kozlowski, W. Walkowiak, Removal of chromium(VI) from aqueous solutions by polymer inclusion membranes, Water Res. 36 (2002) 4870-4876.

[15] S.A. Martinez, M.G. Rodriguez, Dynamical modeling of the electrochemical process to remove $\mathrm{Cr}$ (VI) from wastewaters in a tubular reactor, J. Chem. Technol. Biotechnol 82 (2007) 582-587. 
[16] A. Mittal, L. Krishnan, V.K. Gupta, Removal and recovery of malachite green from wastewater using an agricultural waste material, de-oiled soya, Sep. Purif. Technol. 43 (2005) 125-133.

[17] D. Mohan, K. P. Singh, V. K. Singh, Trivalent chromium removal from wastewater using low cost activated carbon derived from agricultural waste material and activated carbon fabric cloth, J. Hazard. Mater. 135 (2006) 280-295.

[18] L. J. Yu, S. S Shukla, K. L. Dorris, A. Shukla, J. L. Margrave, Adsorption of Chromium from Aqueous Solution by Maple Saw Dust, J. Hazard. Mater. 100 (2003) 53-63.

[19] A. Chakir, J. Bessiere, K. E. Kacemi, B. Marouf, A Comparative Study of the Removal of Trivalent Chromium from Aqueous Solutions by Bentonite and Expanded Perlite, J. Hazard. Mater. 95 (2003) 29-46.

[20] R. Y. Taj, S. Renganathan, N. Partha, G. Baskar, and M. Velan, Removal of chromium from synthetic effluent using Nymphaea rubra, Clean-Soil Air Water 37 (2009) 787-792.

[21] K. Tarangini, A. Kumar, G. R. Satpathy, V. K. Sangal, Statistical optimization of process parameters for $\mathrm{Cr}(\mathrm{VI})$ biosorption onto mixed cultures of Pseudomonas aeruginosa and Bacillus subtilis, Clean-Soil Air Water 37 (2009) 319-327.

[22] S. A. Jabasingh, G. Pavithra, Response surface approach for the biosorption of $\mathrm{Cr}(\mathrm{vi})$ ions by mucor racemosus, Clean-Soil Air Water 38 (2010) 492-499.

[23] X. Dong, L. Q. Ma, Y. Li, Characteristics and mechanisms of hexavalent chromium removal by bio char from sugar beet tailing, J. Hazard. Mater. 190 (2011) 909-915.

[24] S.D. lambert, N.J.D. Graham, Adsorption methods for treating organically coloured upland waters, Environ. Technol. Lett. 10 (1989) 785 - 798.

[25] A. Dawlet, D. Talip, H.Y. Mi, M.Ti, Removal of mercury from aqueous solution using sheep bone charcoal, Procedia Environmental Sciences 18(2013) 800-808.

[26] G. Liu, J.W. Talley, C. Na, S.L. Larson, L.G. Wolfe, Copper Doping Improves

Hydroxyapatite Sorption for Arsenate in Simulated Groundwaters, Environ. Sci. Technol. 44 (2010) 1366 -1372.

[27] J.A. Wilson, J. Demis, I.D. Pulford, S. Thomas, Sorption of $\mathrm{Cr}(\mathrm{III})$ and $\mathrm{Cr}(\mathrm{VI})$ by natural (bone) charcoal, Environ. Geochem. Health. 23 (2001) 291-295.

[28] I. Langmuir, The constitution and fundamental properties of solids and liquids Part I, Solids. J. Am. Chem. Soc. 38 (1916) 2221-2295. 
[29] H.M.F. Freundlich, Uber die Adsorption in Losungen, Z. Phys. Chem. 57 (1906) 385.

[30] V.K. Gupta, S. Sharma, I.S. Yadau, M. Dinesh, Utilisation of biogases fly ash generated in the sugar industry for the removal of phenol and p-nitrophenol from wastewater, J. Chem. Technol. Bio-technol. 71 (1998) 180-186.

[31] M.M. Benjamin, Effects of competing metals and complexing ligands on trace metal adsorption at the oxide/solution interface, PhD Thesis, Standford University, 1978.

[32] M. Arulkumar, K. Thirumalai, P. Sathishkumar, T. Palvannan, Rapid removal of chromium

[33] S. Lagergren, About the theory of so-called adsorption of soluble substances, Kungliga

[34] Y. S. Ho, G. McKay, Pseudo-second order model for sorption processes, Process Biochem. 34 (1999) 451-465.

[35] S. Dahbi, M. Azzi, de la M. Guardia, Removal of Hexavalent Chromium from Wastewaters by Bone Charcoal, Fresenius J. Anal. Chem. 363 (1999) 404-407.

[36] H. Qian, Y. Hu, Y. Liu, M. Zhou, C. Guo, Electrostatic self-assembly of $\mathrm{TiO}_{2}$ nanoparticles onto carbon spheres with enhanced adsorption capability for $\mathrm{Cr}(\mathrm{VI})$, Mater. Lett. 68 (2012) 174-177.

[37] S. Chen, Q. Yue, B. Gao, X. Xu. Equilibrium and kinetic adsorption study of the adsorptive removal of Cr(VI) using modified wheat residue, J. Colloid Interf. Sci. 349 (2010) 256-264.

[38] N.A. Medellin-Castillo, R. Leyva-Ramos, E. Padilla-Ortega, R. Ocampo Perez, J.V. Flores-Cano, M.S. Berber-Mendoza, Adsorption capacity of bone char for removing fluoride from water solution. Role of hydroxyapatite content, adsorption mechanism and competing anions, J. Ind. Eng. Chem. (2014) In Press.

[39] S. Lurtwitayapont, T. Srisatit, Comparison of lead removal by various types of swine bone adsorbents, EnvironmentAsia 3(2010) 32-38.

[40] M. Bhaumik, A. Maity, V.V. Srinivasu, M.S. Onyango, Enhanced removal of Cr(VI) from 487 aqueous solution using polypyrrole/ $\mathrm{Fe}_{3} \mathrm{O}_{4}$ magnetic nanocomposite, J. Hazard. Mater. 190 (2011) 381-390. 
[41] C. Luo, Z. Tian, B.Yang, L. Zhang, S.Yan, Manganese dioxide/iron oxide/acid oxidized multi-walled carbon nanotube magnetic nanocomposite for enhanced hexavalent chromium removal, Chem. Eng. J. 234 (2013) 256-265.

[42] Y. S. Ho, Citation review of Lagergren kinetic rate equation on adsorption reactions, Scientometrics 59 (2004) 171-177.

[43] K. Anupam, S. Dutta, C. Bhattacharjee, S. Datta, Adsorptive removal of chromium(VI) from aqueous solution over powdered activated carbon: optimization through response surface methodology, Chem. Eng. J. 173 (2011) 135-143.

[44] B.H. Hameed, J.M. Salman, A.L. Ahmad, Adsorption isotherm and kinetic modeling of 2,4-

D pesticide on activated carbon derived from date stones. J. Hazard. Mater.163 (2009) 121126.

[45] M. Rao, A.V. Parwate, A.G. Bhole, Removal of $\mathrm{Cr}^{6+}$ and $\mathrm{Ni}^{2+}$ from aqueous solution using bagasse and fly ash, Waste Management 22 (2002) 821-830.

[46] K. Selvi, S. Pattabhi, K. Kadirvelu, Removal of Cr(VI) from aqueous solution by adsorption onto activated carbon, Bioresour. Technol. 80 (2001) 87-89.

[47] K. Kadirvelu, C. Namasivayam, Agricultural by-product as metal adsorbent: sorption of lead (II) from aqueous solution onto coirpith carbon, Environ. Technol. 21 (2000) 10911097.

[48] K. Chojnacka, Equilibrium and kinetic modeling of chromium(III) sorption by animal bones, Chemosphere 59 (2005) 315-320.

[49] B. Kizilkaya, A.A. Tekinay, Y. Dilgin, Adsorption and removal of Cr(II) ions from aqueous solution using pretreated fish bones, Desalination 264 (2010) 37-47.

[50] C. Palmer, R. Puls, Natural attenuation of hexavalent chromium in groundwater and soils, USEPA/540/S-94/505. U.S. Environmental Protection Agency Ground Water Issue. October 
519 Table 1: Chemical and physical properties of the original bone char sample

\begin{tabular}{llll}
\hline Chemical properties & \multicolumn{3}{c}{ Physical Properties } \\
\hline Compounds & Limits $(\%)$ & Compounds & Limits \\
\hline Hydroxyapatite & $70-76$ & Total surface area & $100 \mathrm{~m}^{2} / \mathrm{g}$ \\
Carbon content & $9-11$ & Pore volume & $0.225 \mathrm{~cm}^{3} / \mathrm{g}$ \\
Calcium Carbonate & $7-9$ & Particle size & $250-480 \mu \mathrm{m}$ \\
Calcium Sulfate & $0.1-0.2$ & - & - \\
\hline
\end{tabular}

520

521 Table 2: Tukey HSD test of $\mathrm{Cr}(\mathrm{VI})$ removal at various $\mathrm{pH}$

\begin{tabular}{llll}
\hline pH values & $\begin{array}{l}\text { mean difference in } \% \\
\text { Cr(VI) removal }\end{array}$ & HSD value & Comments \\
\hline 1 and 2 & 31.75 & 6.09 & Significant difference \\
1 and 3 & 49.5 & 6.09 & Significant difference \\
1 and 5 & 51.5 & 6.09 & Significant difference \\
1 and 7 & 59.25 & 6.09 & Significant difference \\
1 and 9 & 61.75 & 6.09 & Significant difference \\
2 and 3 & 17.75 & 6.09 & Significant difference \\
2 and 5 & 19.75 & 6.09 & Significant difference \\
2 and 7 & 27.5 & 6.09 & Significant difference \\
2 and 9 & 30 & 6.09 & Significant difference \\
3 and 5 & 2 & 6.09 & not Significant difference \\
3 and 7 & 9.75 & 6.09 & Significant difference \\
3 and 9 & 12.25 & 6.09 & Significant difference \\
5 and 7 & 7.75 & 6.09 & Significant difference \\
5 and 9 & 10.25 & 6.09 & Significant difference \\
7 and 9 & 2.5 & 6.09 & not Significant difference \\
\hline
\end{tabular}

522

523 Table 3: Coefficients of Langmuir and Freundlich model

\begin{tabular}{|c|c|c|c|c|c|c|c|}
\hline \multicolumn{3}{|c|}{ Langmuir model } & \multirow{2}{*}{$\begin{array}{l}\text { Experimental } \\
\mathrm{q}_{\mathrm{m}}\end{array}$} & \multirow{2}{*}{$\begin{array}{l}\text { Deviation } \\
q_{m}\end{array}$} & \multicolumn{3}{|c|}{ Freundlich model } \\
\hline $\mathrm{R}^{2}$ & $\mathrm{~K}_{\mathrm{L}}$ & $\mathrm{q}_{\mathrm{m}}$ & & & $\mathrm{R}^{2}$ & $\mathrm{~K}_{\mathrm{F}}$ & $1 / \mathrm{n}$ \\
\hline- & $(\mathrm{L} / \mathrm{mg})$ & $(\mathrm{mg} / \mathrm{g})$ & $(\mathrm{mg} / \mathrm{g})$ & $\%$ & - & $\begin{array}{l}(\mathrm{mg} / \mathrm{g}) \\
(\mathrm{L} / \mathrm{mg})^{1 / \mathrm{n}}\end{array}$ & - \\
\hline 0.9871 & 0.0023 & 8.4 & 4.8 & $43 \%$ & 0.9745 & 0.138 & 0.5589 \\
\hline
\end{tabular}


Table 4: The adsorptive capacities of various adsorbents for $\mathrm{Cr}(\mathrm{VI})$

\begin{tabular}{llll}
\hline Adsorbent & $\mathrm{q}_{\mathrm{m}}(\mathrm{mg} / \mathrm{g})$ & $\mathrm{pH}$ & Reference \\
\hline Bone char & 8.41 & 1 & Present study \\
Oak bark wood char & 4.62 & 2 & Mohan et al., 2011 \\
Powdered activated carbon & 0.03 & 2 & Rao et al., 2002 \\
Coconut tree sawdust derived & 3.5 & 3 & Selvi et al., 2001 \\
activated carbon & & & \\
\hline
\end{tabular}

526

527 Table 5: Coefficients of the first and second order kinetic model

\begin{tabular}{llllll}
\hline \multicolumn{2}{l}{ First order kinetic model } & \multicolumn{3}{l}{ Second order kinetic model } \\
\hline $\mathrm{R}^{2}$ & $\mathrm{~K}_{1}$ & $\mathrm{q}_{\mathrm{e}}$ & $\mathrm{R}^{2}$ & $\mathrm{~K}_{2}$ & $\mathrm{q}_{\mathrm{e}}$ \\
\hline- & $\left(\mathrm{h}^{-1}\right)$ & $(\mathrm{mg} / \mathrm{g})$ & - & $\left(\mathrm{g} \cdot \mathrm{mg}^{-1} \cdot \mathrm{h}^{-1}\right)$ & $(\mathrm{mg} / \mathrm{g})$ \\
\hline 0.9191 & 1.813 & 0.1317 & 1 & 219 & 0.25 \\
\hline
\end{tabular}

531 Fig. 1: Variation of chromium species depending of Eh-pH change [50].

533 Fig. 2: Removal efficiencies of $\mathrm{Cr}(\mathrm{VI})$ onto bone char as sorbent with (a) different pHs at initial

$534 \mathrm{Cr}(\mathrm{VI})$ concentration of $10 \mathrm{mg} / \mathrm{L}$, bone-char of $2 \mathrm{~g}$; (b) different dosages of bone-char at $\mathrm{pH}$ of 1 , 535 initial $\mathrm{Cr}(\mathrm{VI})$ concentration of $10 \mathrm{mg} / \mathrm{L}$ and c) different initial $\mathrm{Cr}(\mathrm{VI})$ concentration: $\mathrm{pH}$ of 1 and $5362 \mathrm{~g}$ bone-char

538 Fig. 3: Sorption capacities of bone-char with time for different initial $\mathrm{Cr}(\mathrm{VI})$ concentrations: $\mathrm{pH}$ 539 of 1 , bone-char of $2 \mathrm{~g}$.

541 Fig. 4: Plots of a) Langmuir and b) Freundlich isotherms for $\mathrm{Cr}(\mathrm{VI})$ sorption onto bone char. pH:

542 1; bone char: $2 \mathrm{~g}$. The solid line is experimental data and dashed line is the linearized Langmuir 543 model. 
544 Fig. 5: Plots of a)First-order kinetic model and b) second-order kinetic models for $\mathrm{Cr}(\mathrm{VI})$

545 sorption onto bone char at optimum initial concentration of $10 \mathrm{mg} / \mathrm{L}$. pH: 1 ; amount of bone 546 char: $2 \mathrm{~g}$. 


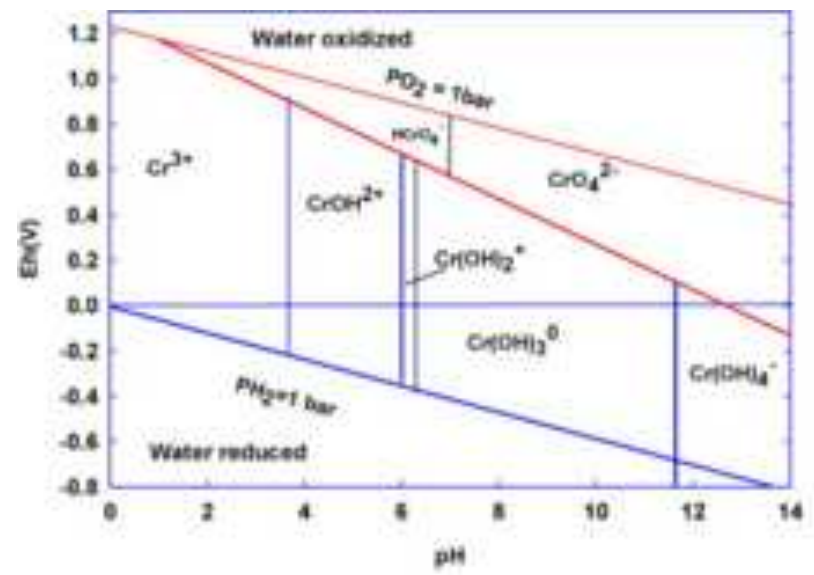

Figure 1 


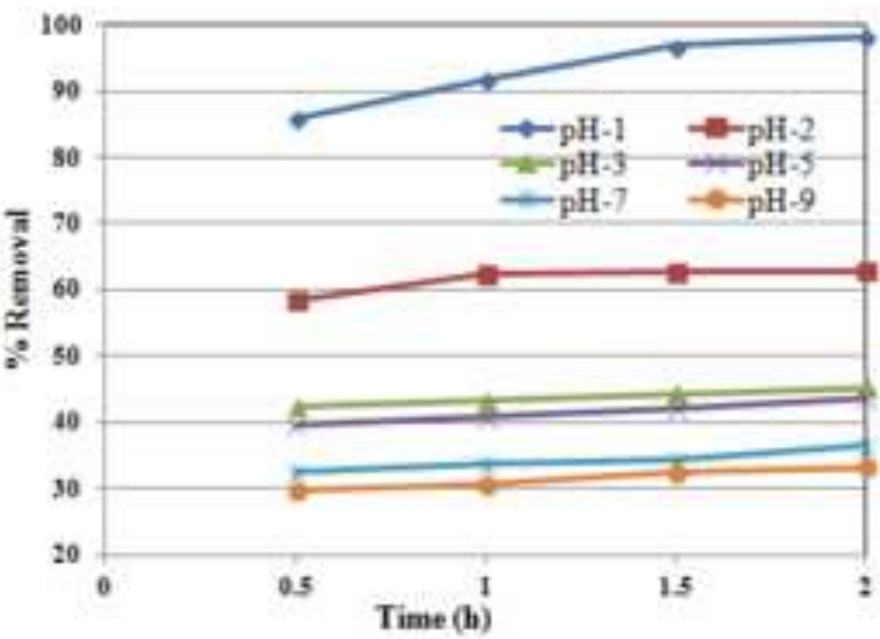

(a)

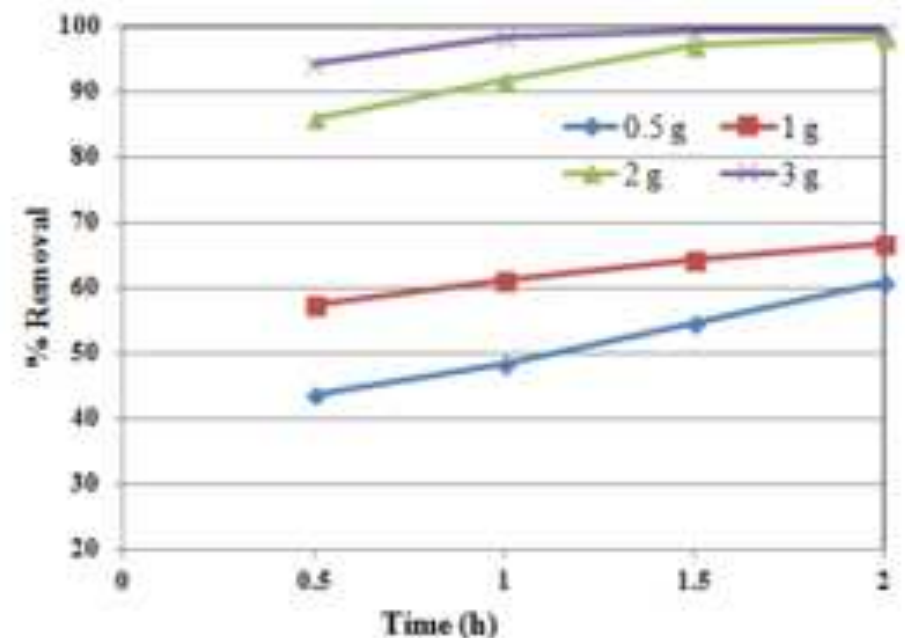

(b)

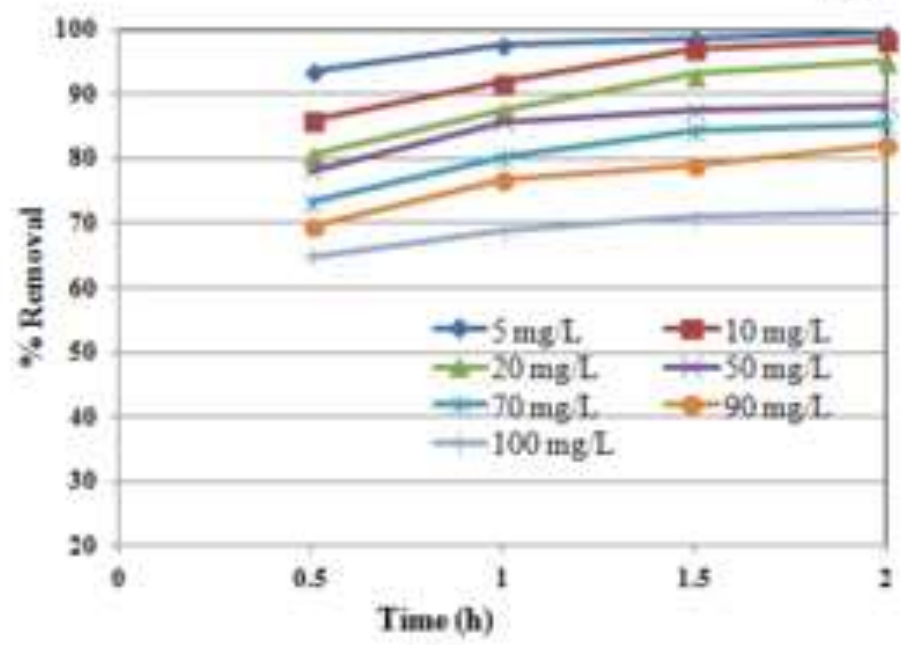

(c)

Fingre 2 


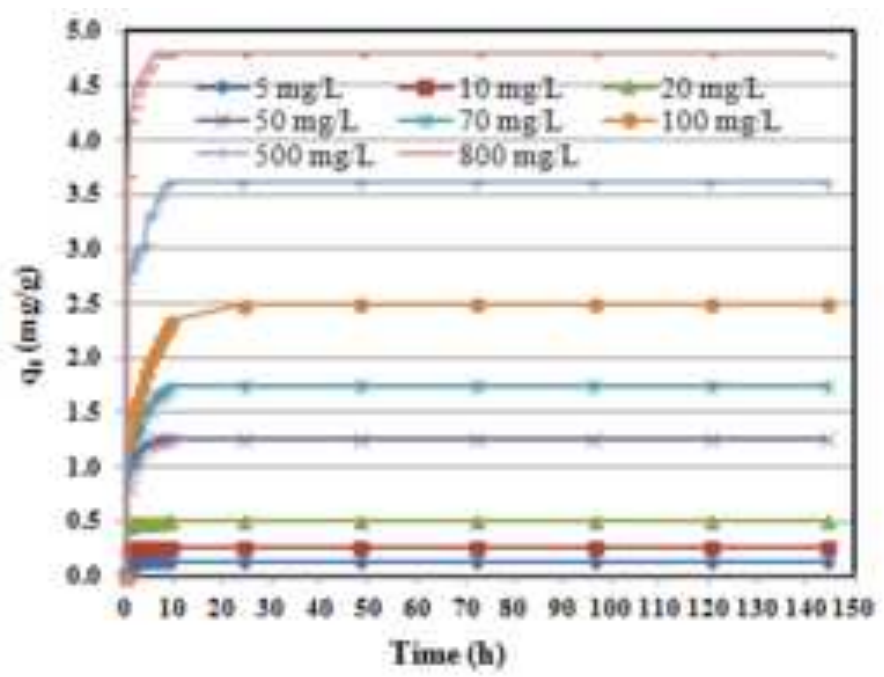

Figure 3 


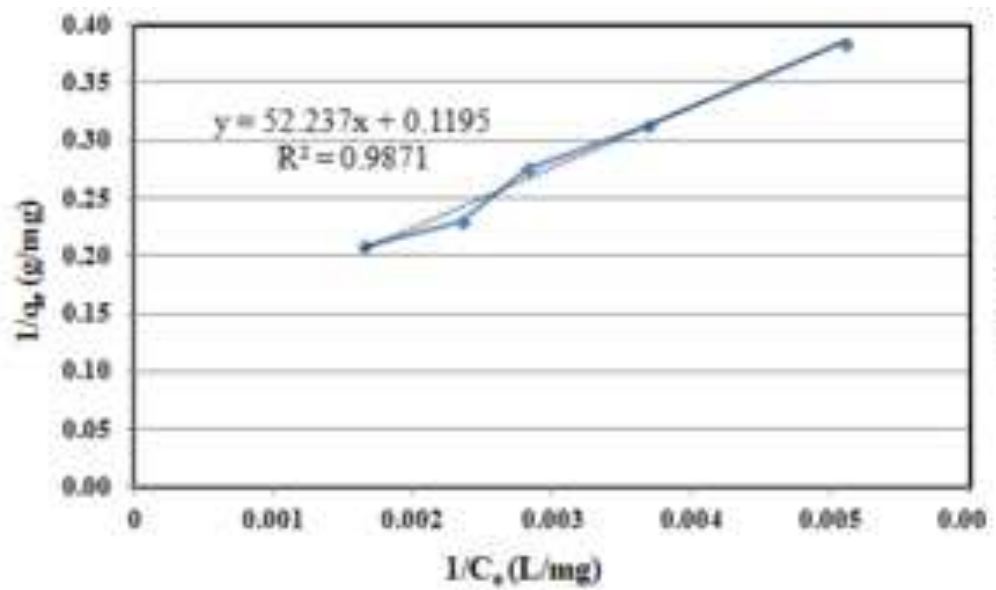

(a)

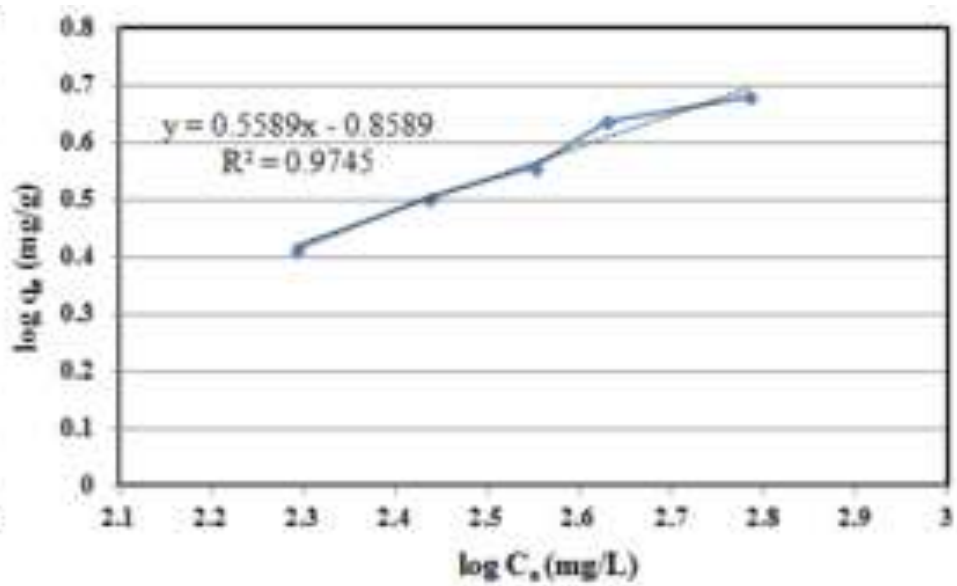

(b)

Figure 4 


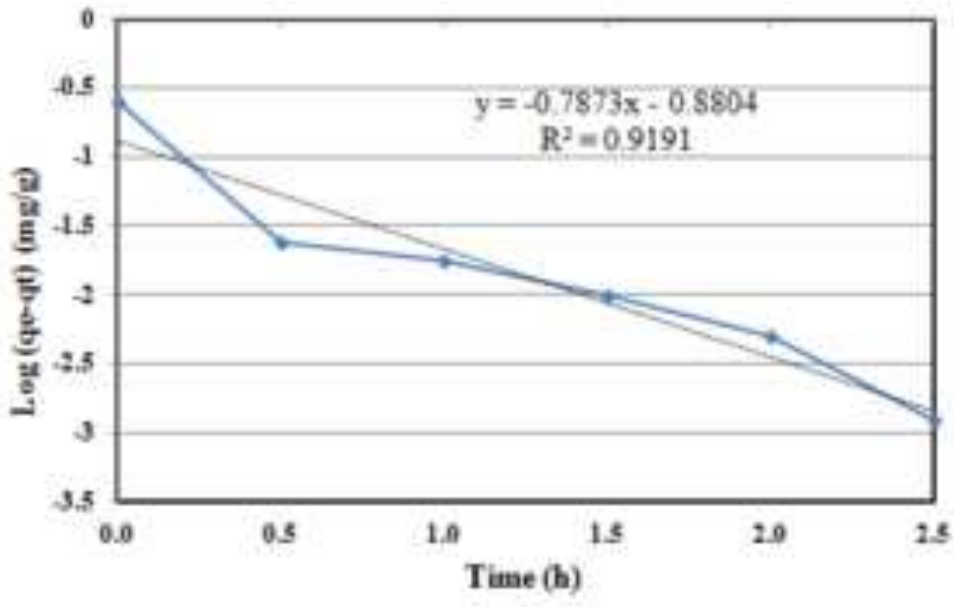

(a)

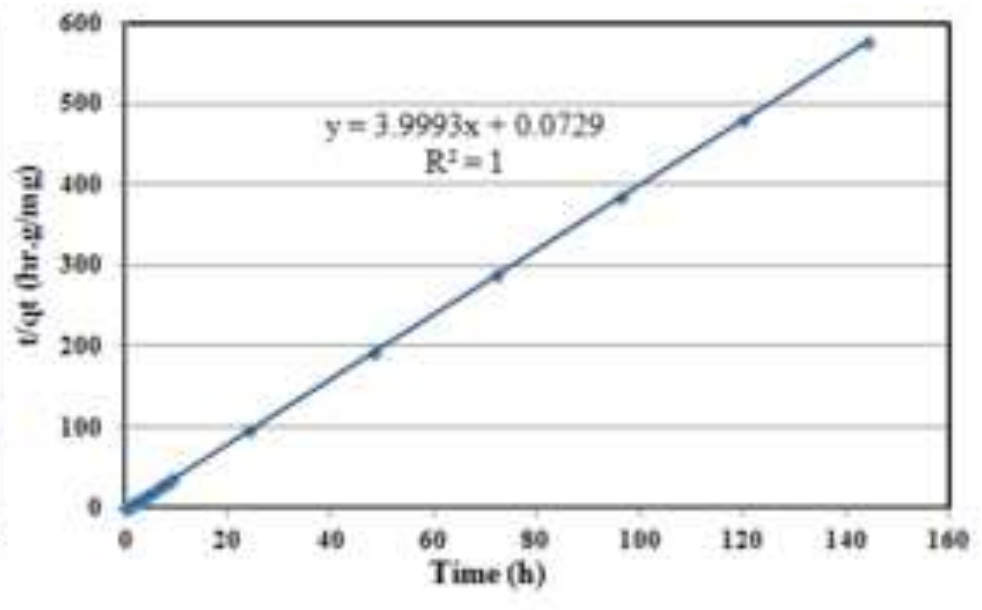

(b)

Fipare 5 